\title{
Recognition of mitochondrial DNA deletion syndrome with non-neuromuscular multisystemic manifestation
}

\author{
Lee-Jun C. Wong, PhD
}

\begin{abstract}
Purpose: To correlate the molecular characteristics of the mtDNA deletions with clinical phenotypes. Methods: Southern analysis and polymerase chain reaction (PCR)/DNA sequencing were used to determine the size and location of deletions in 16 patients with mtDNA deletion syndrome. An additional 48 reported cases from the literature were also included in the statistical analysis. Results: The common 5-kb deletion is found in eight of nine patients with Kearns-Sayre syndrome (KSS), mitochondrial myopathies (MM), or progressive external ophthalmoplegia (PEO). The rare/novel deletions were found in six of seven patients with extra-neuromuscular multisystemic manifestations and infantile/early childhood onset. Conclusions: Patients with mtDNA deletion syndrome who manifest non-neuromuscular multisystemic disorders at a very young age usually harbor mutant mtDNA with novel or rare deletions in every tissue analyzed. For this group of patients, it is possible to use the less invasive blood specimens instead of muscle biopsies for molecular diagnosis. Overwhelmingly, the common 5-kb deletion is mostly seen in the muscle specimens of patients with KSS and age of onset after the second decade of life. Genet
\end{abstract} Med 2001:3(6):399-404.

Key Words: mtDNA deletion, Kearns-Sayre syndrome, Pearson syndrome

Large mitochondrial DNA (mtDNA) deletions were first discovered in the muscle of patients with mitochondrial myopathies (MM) and Kearns-Sayre syndrome (KSS) (OMIM530000). ${ }^{1-3}$ The clinical diagnostic criteria of KSS include progressive external ophthalmoplegia (PEO, OMIM555000), onset before 20 years of age, pigmentary retinopathy, and one or more of the following: cerebellar ataxia, cardiac conduction defect, and elevated protein concentration of greater than $1 \mathrm{~g} / \mathrm{L}$ in cerebrospinal fluid. ${ }^{4}$ However, patients with mtDNA deletions may manifest with only PEO or MM. On the other hand, clinical presentation of mtDNA deletion syndrome in infants and young children can be quite heterogeneous. These patients may present a broad spectrum of clinical symptoms that can not be readily related to the neuromuscular and cardiac conditions seen in KSS patients. One such example is Pearson syndrome (OMIM557000), which is characterized by infantile manifestation of sideroblastic anemia with vacuolization of bone marrow precursor cells and pancreatic dysfunction. ${ }^{5}$ Patients who survive the hematopoietic and pancreatic dysfunction of infancy can go on to develop KSS at a later age. Recently, mtDNA deletion syndromes have been reported in patients with various clinical manifestations, including Addison disease,${ }^{6-8}$ atypical Pearson presentation, ${ }^{9-11}$ cyclic vomiting, ${ }^{6,9,12}$ severe renal tubulopathy, ${ }^{11}$ hepatic dys-

From the Institute for Molecular and Human Genetics, Georgetown University Medical Center, Washington, DC 20007.

Lee-Jun C. Wong, PhD, Institute for Molecular and Human Genetics, Georgetown University Medical Center, M4000, 3800 Reservoir Road, NW, Washington, DC 20007.

Received: June 1, 2001.

Accepted: August 22, 2001 function, ${ }^{13}$ dysarthria, ${ }^{9,10}$ organic acidopathy, ${ }^{14,15}$ and hypoparathyroidism and hypocalcemia.6,16,17 The mitochondrial DNA deletion syndrome is defined as any case with a single mtDNA deletion, regardless of the clinical phenotype. In KSS, deleted mtDNA occurs mainly in muscle and not always in leukocytes. ${ }^{1,18}$ In addition, the patient's mother usually is not a carrier. Approximately one-third of the patients with KSS have the common 5-kb (np8469-np13447) deletion. ${ }^{3,19}$ Although onset before the age of 20 years is one of the diagnostic criteria for KSS, many patients with chronic progressive external ophthalmoplegia (CPEO) or MM without other severe KSS symptoms often presented neuromuscular symptoms at a much older age. ${ }^{19}$ In contrast, patients manifesting severe multisystemic disorders at a very young age may not show definitive signs of KSS. This group of patients either died at a young age without diagnosis or was not diagnosed until more clear symptoms of KSS developed at a later age. Because of the increasing awareness of the heterogeneous clinical presentations of mitochondrial disorders, more young children with undefined multisystemic illness are molecularly diagnosed with mtDNA deletions. The aim of this study is to correlate the molecular genetic findings of mtDNA deletions with clinical manifestations in patients with KSS, CPEO, or MM, and those with extra-neuromuscular multisystemic complications with or without KSS. Our observation is that most patients with mtDNA deletions manifesting non-neuromuscular multisystemic disorders early in life have mutant mtDNA in various tissues including blood. These patients usually have novel deletions instead of the common 5-kb deletion, and the novel mtDNA deletions are usually lacking the flanking repeats. 


\section{METHODS}

Subjects of this study included all cases sent by clinicians for mtDNA analysis between 1995 and 1997 to Childrens Hospital Los Angeles (1,300 unrelated individuals), and 1998 and 2000 to Georgetown University Medical Center (1,100 unrelated individuals). Some of these patients had strong clinical indications of mitochondrial DNA disorders, some were referred for ruling out common mutations in mtDNA. The molecular diagnosis of mtDNA included multiplex PCR/ASO analysis of 11 common point mutations (A3243G, T3271C, A8344G, T8356C, T8993G, T8993C, G8363A, G11778A, G3460A, T14484C, G14459A) and Southern analysis of mtDNA deletions and rearrangement. ${ }^{20,21}$ Sixteen patients with mtDNA deletions detected by Southern analysis were further characterized by PCR and BigDye DNA sequencing to determine the exact location and size of deletion. ${ }^{7,10}$

\section{RESULTS}

Table 1 summarizes the age at diagnosis, major clinical manifestations, molecular genetic characterization of the mtDNA deletions, and the proportion of mutant mtDNA in various tissues analyzed. Among the 16 patients, 9 presented with KSS, mitochondrial myopathies (MM), or progressive external ophthalmoplegia (PEO). This group of patients was diagnosed at an average age of 37 years. Eight $(89 \%)$ of them had the common 5-kb deletion with direct repeats of 13-bp flanking the deleted region (Patients 1, 2, 4, 5, 7, 9, and 15). The deleted mutant mtDNA molecules were found in muscle of patients with the findings of mitochondrial myopathies and ragged red fibers. The blood mtDNA was available from two of these patients (Patients 4 and 15). Molecular analysis revealed that the deleted mtDNA was not present in the blood specimen of either patient. This finding is consistent with previous reports that deleted mtDNA was usually not detected in the leukocytes of patients with KSS. ${ }^{1,18}$ The mutant mtDNA was also absent in hair follicles and buccal mucosal cells from one patient (Patient 4). Conversely, the remaining seven patients (Patients 3 , $6,8,12,13,14$, and 16) presenting at infancy or early childhood with undefined, multisystemic complications were diagnosed at an average age of 3.6 years. This group of patients had diverse clinical manifestations, including endocrinopathy, gastroenterologic problems, atypical Pearson syndrome, organic acidopathy, and renal dysfunction. Only one (14\%) of these younger patients had the common 5-kb deletion. Unlike the KSS, the deleted mutant mitochondrial DNAs were present in various tissues (Patients 6, 12, and 13), including blood. Although mtDNA deletions usually occur sporadically without the carrier mother, we did find one asymptomatic mother who carried the same deletion/duplication mtDNA as her affected child (Patient 8). ${ }^{12}$ In addition, five patients (70\%) harbored novel mtDNA deletions without the direct repeats at the flanking sequence. Because the patients who presented extra-neuromuscular multisystemic disorders with or without KSS seemed to have mutant mtDNA in every tissue, these patients may also have mutant mtDNA in their germ cells. Thus, it is possible for the female patients to pass the deleted mtDNA to her offsprings, if they survive to adulthood.

\section{DISCUSSION}

Our data suggest that the common $5-\mathrm{kb}$ deleted mtDNA is preferentially eliminated in blood and perhaps also in tissues other than muscle and nerve. The mtDNA with unique, rare deletions are more likely to remain in every tissue, perhaps due to the molecular characteristics of the deletion and the tissue specific selection and threshold. There seems to be an association between the presence of the novel mutant mtDNA in every tissue and earlier onset of the disease with more severe and broader spectrum of multisystemic clinical manifestations. To substantiate this observation, we surveyed a total of 30 reports on the mtDNA deletion cases reported in the past 4 years. Excluding the multiple mtDNA deletions caused by autosomal nuclear gene defects and the reports lacking either the molecular or the clinical studies, only 18 reports had complete clinical and molecular characterization with a total of 48 patients. Thirteen reports were single patient cases with various clinical presentations. ${ }^{8,9,11,15,16,22-29}$ One report had 4 patients with hypoparathyroidism, ${ }^{17}$ another had 7 patients with KSS, ${ }^{3}$ one had 3 patients with Pearson syndrome, ${ }^{14}$ one had 2 patients with multiple endocrine problems, ${ }^{6}$ and another had $20 \mathrm{KSS}$ patients. ${ }^{19}$ Overall, 34 patients had typical KSS, CPEO, or MM, 14 patients had multisystemic disorders with initial presentation of non-neural, nonmuscular clinical manifestations. Table 2 summarizes the correlation of molecular deletions with clinical presentation. The data of the present study and the previous reports demonstrate that all, except one, patients who presented with multisystemic complications without neuromuscular involvement have the rare or novel deletions. The presence of deleted mtDNA in the blood was analyzed in a total of six patients with KSS. Two were positive and four were negative. In contrast, among the blood samples analyzed from 18 of the 21 patients with extra-neuromuscular multisystemic disorders, all had deleted mutant mtDNA in the blood. The age of diagnosis was also correlated with clinical presentation (Table 3). All 21 patients with the extra-neuromuscular multisystemic disorders manifested the disease before age $10(P<0.0001)$, whereas most of the patients with KSS/MM/CPEO began to have symptoms after the second decade of life. The average age at diagnosis for patients with $\mathrm{KSS} / \mathrm{CPEO} / \mathrm{MM}$ was 37, 28, and 30 years, from our study, previous reports, and combined group, respectively. The average age at diagnosis for patients with extra-neuromuscular multisystemic presentations was 3.6, 6, and 5.2 years, respectively. In our study, four of seven patients manifested severe multisystemic disease at infancy, and three of them presented at early childhood. Review of the earlier reports showed that in many of the early onset, multisystemic cases, the initial presentation of the disease was confusing and the diagnosis was not clear until later when the neuromuscular involvement of the KSS became more apparent. The discrepancy between our study (3.6 years of age) and 
Mitochondrial DNA deletion syndrome

Table 1

Correlation of molecular genetics and clinical presentations of patients with mtDNA deletions

\begin{tabular}{|c|c|c|c|c|}
\hline $\mathrm{Pt}$ & $\begin{array}{l}\text { Age at diagnosis } \\
\text { (years) }\end{array}$ & Major clinical manifestation & Tissue (\% mutant) & Location of deletion (size of deletion) \\
\hline 1 & 20 & KSS & $\operatorname{Muscle}^{a}(45)$ & 8469-13447 (common $5 \mathrm{~kb}$ ), direct repeat \\
\hline 2 & 26 & KSS & Muscle (10) & 8469-13447 (common $5 \mathrm{~kb}$ ), direct repeat \\
\hline 3 & 6 & Multisystemic & Blood (70) & 8623-15662 (7 kb), direct repeat \\
\hline 4 & 28 & KSS & $\begin{array}{l}\text { Muscle (33) } \\
\text { Blood (0) } \\
\text { Hair follicles (0) } \\
\text { Buccal cells }(0)\end{array}$ & 8469-13447 (common $5 \mathrm{~kb}$ ), direct repeat \\
\hline 5 & 60 & $\begin{array}{l}\text { CPEO } \\
\text { MM }\end{array}$ & Muscle (45) & 8469-13447 (common $5 \mathrm{~kb}$ ), direct repeat \\
\hline 6 & $6^{b}$ & $\begin{array}{l}\text { Addison disease } \\
\text { Endocrine problem } \\
\text { Renal failure } \\
\text { Multisystemic } \\
\text { Symptoms of KSS became } \\
\text { apparent after molecular } \\
\text { diagnosis was confirmed }\end{array}$ & $\begin{array}{l}\text { Blood (67) } \\
\text { Muscle (65) } \\
\text { Liver (95) } \\
\text { Spleen (81) } \\
\text { Heart (60) } \\
11 \text { other autopsy } \\
\quad \text { tissues (20-95) }\end{array}$ & 8469-13447 (common $5 \mathrm{~kb}$ ), direct repeat \\
\hline 7 & 44 & $\begin{array}{l}\text { CPEO } \\
\text { KSS }\end{array}$ & Muscle (70) & 8469-13447 (common $5 \mathrm{~kb}$ ), direct repeat \\
\hline 8 & 2 & $\begin{array}{l}\text { Cyclic vomiting } \\
\text { GI reflux } \\
\text { Seizure } \\
\text { Lactic acidosis } \\
\text { Multisystemic without KSS }\end{array}$ & $\begin{array}{l}\text { Blood (90) } \\
\text { Mother's blood (20) }\end{array}$ & 6718-14834 (8.1 kb), novel del/dup \\
\hline 9 & 16 & KSS & Muscle (62) & 8469-13447 (common $5 \mathrm{~kb}$ ), direct repeat \\
\hline 10 & 67 & MM & Muscle (16) & Location not determined $(3.5 \mathrm{~kb})$, novel \\
\hline 11 & 34 & KSS & Muscle (51) & 8469-13447 (common $5 \mathrm{~kb}$ ), direct repeat \\
\hline 12 & 8 & $\begin{array}{l}\text { Macrocytic anemia } \\
\text { Short stature } \\
\text { Flaky skin } \\
\text { Ataxia } \\
\text { Abnormal MRI } \\
\text { Multisystemic } \\
\text { Some KSS symptoms began to } \\
\text { show at age } 8\end{array}$ & $\begin{array}{l}\text { Blood (21) } \\
\text { Hair follicle (38) } \\
\text { Muscle (55) } \\
\text { Cheek cells (57) } \\
\text { Mother's blood (0) }\end{array}$ & 10560-14980 (4.4 kb), novel, no direct repeat \\
\hline 13 & 1 & $\begin{array}{l}\text { Pearson } \\
\text { Macrocytic anemia } \\
\text { Developmental delay } \\
\text { Organic aciduria } \\
\text { Lactic acidosis } \\
\text { Failure to thrive } \\
\text { Constipation } \\
\text { Multisystemic without KSS }\end{array}$ & $\begin{array}{l}\text { Blood }(>90) \\
\text { Hair follicle }(\sim 90) \\
\text { Buccal cells }(\sim 90)\end{array}$ & $12103-14414(2.3 \mathrm{~kb})$, direct repeat \\
\hline 14 & $1^{c}$ & $\begin{array}{l}\text { Developmental delay } \\
\text { Failure to thrive } \\
\text { Lactic acidosis } \\
\text { Hypotonia } \\
\text { Muscle weakness } \\
\text { Fatigue } \\
\text { Diarrhea } \\
\text { Renal failure } \\
\text { Apnea } \\
\text { Organic aciduria } \\
\text { Elevated transaminase } \\
\text { Multisystemic without KSS }\end{array}$ & Blood (65) & 8536-15642 (7.1 kb), novel, no direct repeat \\
\hline 15 & 36 & KSS & $\begin{array}{l}\text { Muscle (64) } \\
\text { Blood (0) }\end{array}$ & 8469-13447 (common $5 \mathrm{~kb}$ ), direct repeat \\
\hline 16 & 1 & $\begin{array}{l}\text { Pearson syndrome } \\
\text { multisystemic }\end{array}$ & Blood (80) & $10418-15570(5.15 \mathrm{~kb})$, novel, no direct repeat \\
\hline
\end{tabular}

${ }^{a}$ All muscle specimens in this study are skeletal muscle unless otherwise indicated.

${ }^{b}$ Died at age 8 .

${ }^{c}$ Died at age 1 . 
Table 2

Correlation of molecular type of mtDNA deletion with clinical presentation ${ }^{a}$

\begin{tabular}{|c|c|c|c|c|c|c|c|}
\hline \multirow[b]{2}{*}{$\begin{array}{l}\text { Clinical } \\
\text { presentation }\end{array}$} & \multicolumn{3}{|c|}{ Common 5 -kb deletion } & \multicolumn{3}{|c|}{ All other deletions } & \multirow[b]{2}{*}{$\begin{array}{c}\text { Combined } \\
\text { total }\end{array}$} \\
\hline & $\begin{array}{l}\text { Previous } \\
\text { reports }\end{array}$ & $\begin{array}{l}\text { This } \\
\text { study }\end{array}$ & Combined & $\begin{array}{l}\text { Previous } \\
\text { reports }\end{array}$ & $\begin{array}{l}\text { This } \\
\text { study }\end{array}$ & Combined & \\
\hline KSS/CPEO/MM & 11 & 8 & 19 & 23 & 1 & 24 & 43 \\
\hline $\begin{array}{l}\text { Non- } \\
\text { neuromuscular } \\
\text { multisystemic } \\
\text { with or } \\
\text { without KSS }\end{array}$ & 0 & 1 & 1 & 14 & 6 & 20 & 21 \\
\hline Total & 11 & 9 & 20 & 37 & 7 & 44 & 64 \\
\hline
\end{tabular}

${ }^{a} P$ values: 0.041 (this study), 0.021 (previous studies), 0.003 (combined).

Table 3

Correlation of age of diagnosis with clinical presentations ${ }^{a}$

\begin{tabular}{|c|c|c|c|c|c|c|c|}
\hline \multirow[b]{2}{*}{$\begin{array}{l}\text { Clinical } \\
\text { presentation }\end{array}$} & \multicolumn{3}{|c|}{ Diagnosis at age $<10$ years } & \multicolumn{3}{|c|}{ Diagnosis at age $>10$ years } & \multirow[b]{2}{*}{$\begin{array}{c}\text { Combined } \\
\text { total }\end{array}$} \\
\hline & $\begin{array}{c}\text { Previous } \\
\text { reports }\end{array}$ & $\begin{array}{l}\text { This } \\
\text { study }\end{array}$ & Combined & $\begin{array}{c}\text { Previous } \\
\text { reports }\end{array}$ & $\begin{array}{l}\text { This } \\
\text { study }\end{array}$ & Combined & \\
\hline $\mathrm{KSS} / \mathrm{CPEO} / \mathrm{MM}$ & 5 & 0 & 5 & 29 & 9 & 38 & 43 \\
\hline $\begin{array}{l}\text { Non- } \\
\text { neuromuscular } \\
\text { multisystemic } \\
\text { with or } \\
\text { without KSS }\end{array}$ & 14 & 7 & 21 & 0 & 0 & 0 & 21 \\
\hline Total & 19 & 7 & 26 & 29 & 9 & 38 & 64 \\
\hline
\end{tabular}

${ }^{a} P$ values: 0.0001 (this study), $<0.0001$ (previous studies), $<0.00001$ (combined).

previous reports (6 years of age) is probably reflecting the increasing awareness of mitochondrial mtDNA deletion as the etiology of undefined multisystemic disorders leading to earlier diagnosis. In our study, before 1998, 7 of 10 patients (70\%) (Patients 1 to 10 in Table 1) were diagnosed as KSS, MM, or CPEO, at an older age, whereas after 1998, only 2 of 6 (33\%) were diagnosed as KSS. Three of the remaining four young patients with infantile onset multisystemic disease were diagnosed molecularly at age 1 with mtDNA deletions. It should be noted that most of the KSS patients with abnormal muscle biopsy findings were referred by pathologists, whereas patients with multisystemic disorders without initial neuromuscular involvement were usually referred by geneticists, neurologists, endocrinologists, or clinicians of other medical specialty.
Thus, there might be a slight bias, because earlier referrals were more likely from pathologists for abnormal muscle biopsy findings. Whereas the later referrals were more likely reflecting the increased awareness of mtDNA deletion syndrome in young patients with multisystemic disorders and with referrals from diverse specialties of medical practice. When the molecular characteristic of mtDNA deletion was correlated with the age of onset, it was found that patients with rare/novel deletions were significantly associated with early age of onset $(<10$ years of age), and the patients with common deletions had later age of onset $(P=0.0087,0.0324$, and 0.0008 , respectively, for this, previous, and combined studies, Table 4 ).

It is generally accepted that blood cells may have a replicative advantage for eliminating deleted mtDNA, whereas muscle

Table 4

Correlation of age of onset with molecular characteristics of mtDNA deletion ${ }^{a}$

\begin{tabular}{|c|c|c|c|c|c|c|c|}
\hline \multirow[b]{2}{*}{$\begin{array}{l}\text { MtDNA } \\
\text { deletion }\end{array}$} & \multicolumn{3}{|c|}{ Onset at age $<10$ years } & \multicolumn{3}{|c|}{ Onset at age $>10$ years } & \multirow[b]{2}{*}{$\begin{array}{c}\text { Combined } \\
\text { total }\end{array}$} \\
\hline & $\begin{array}{c}\text { Previous } \\
\text { reports }\end{array}$ & $\begin{array}{l}\text { This } \\
\text { study }\end{array}$ & Combined & $\begin{array}{c}\text { Previous } \\
\text { reports }\end{array}$ & $\begin{array}{l}\text { This } \\
\text { study }\end{array}$ & Combined & \\
\hline Common $5 \mathrm{~kb}$ & 1 & 1 & 2 & 10 & 8 & 18 & 20 \\
\hline $\begin{array}{l}\text { All other } \\
\text { deletions }\end{array}$ & 18 & 6 & 24 & 19 & 1 & 20 & 44 \\
\hline Total & 19 & 7 & 26 & 29 & 9 & 38 & 64 \\
\hline
\end{tabular}

${ }^{a} P$ values: 0.0087 (this study), 0.0324 (previous studies), 0.0008 (combined). 
cells tend to accumulate deleted mutant mtDNA. ${ }^{30-32}$ Therefore, the hematopoietic problems of patients with Pearson syndrome may disappear and the neurologic symptoms of KSS may develop at a later age. However, the selection may also depend on the molecular characteristics of the mtDNA deletion, such as the absence of the flanking repeat sequence. As shown in our data, the rare/novel deletions appear to be present in most of the tissues, including blood, liver, and kidney. Most of these (70\%) do not have the flanking repeats. Patients with these rare deletions are more likely to have heterogeneous, multisystemic clinical manifestations that are often not observed in patients with KSS/MM/CPEO $(P<0.05)$. Only 1 of the 21 patients with the multisystemic extra-neuromuscular disease had the common 5-kb deletion. One possibility is that the patients with the $5-\mathrm{kb}$ common deletions are not all reported in the literature. However, the molecular characterization was performed after the unusual clinical manifestation was recognized; therefore, the lack of reporting should not be the reason. The other explanation is that the mutant mtDNA of the common 5-kb deletion is subject to tissue specific elimination. In addition to tissue specificity, the sporadic mtDNA deletions of KSS/MM/CPEO patients without extraneuromuscular manifestations may result from a relatively late embryonic event, which may be more confined, thus, a less multisystemic disease, later onset, and not passed on by mothers to their children. We favor the later two explanations, based on the observation that most of the common 5 -kb deleted mtDNAs were not present in blood, yet most of the mutant mtDNAs with rare type of deletions were present in blood, muscle, and other tissues, resulting in multisystemic disorders. It has been reported that mutant mtDNA is selectively eliminated in rapidly dividing cells, whereas in nondividing cells such as skeletal muscle the mutant mtDNA accumulates. ${ }^{31,33}$

In the past, the performance of an invasive muscle biopsy was the only reliable means of making a molecular diagnosis, because deleted mutant mtDNA were often not found in the blood of KSS patients. Therefore, finding the unusual mtDNA deletions in multiple tissues provides an advantage for the definitive diagnosis of mtDNA deletion syndromes in young children. Our data suggest that, if a patient suspected of mitochondrial disease presents with undefined multisystemic disorder in early childhood or infancy, a blood specimen can be used for molecular diagnosis. If the patient indeed has an mtDNA deletion, most likely it will be detected in the blood and the patient can be spared a muscle biopsy. On the other hand, muscle specimens should be analyzed in patients with KSS, CPEO, or $\mathrm{MM}$, because most often, the mutant mtDNA will not be found in the blood specimens of these patients. A needle muscle biopsy would provide an adequate amount of tissue for Southern analysis of mtDNA deletions (Patient 15 in Table 1). PCR-based assays can be used for more sensitive detection of a low percentage of deleted mtDNAs or the detection of deleted $\mathrm{mtDNA}$ in noninvasive tissue specimens such as hair follicles and buccal cells. ${ }^{10}$

\section{Acknowledgments}

This study is partially supported by a grant from Muscular Dystrophy Association (MDA). The author thanks all the physicians who referred patients contributing to this study and all the fellows and technicians who participated in the molecular diagnosis and discussion of individual cases.

\section{References}

1. Holt IJ, Harding AE, Morgan-Hughes JA. Deletions of muscle mitochondrial DNA in patients with mitochondrial myopathies. Nature 1988;331:717-719.

2. Holt IJ, Harding AE, Morgan-Hughes JA. Deletions of muscle mitochondrial DNA in mitochondrial myopathies: sequence analysis and possible mechanism. Nucleic Acids Res 1989;17:4465-4469.

3. Zeviani M, Moraes CT, DiMauro S, Nakase H, Bonilla E, Schon EA, Rowland LP. Deletions of mitochondrial DNA in Kearns-Sayre syndrome. Neurology 1988;38: 1339-1346.

4. Hammans SR, Morgan-Hughes JA. Mitochondrial myopathies: clinical features, investigation, treatment and gentic counseling. In: Schapira A, DiMauro S, editors. Mitochondrial disorders in neurology. Oxford: Butterworth-Heinmann, 1994:49-74.

5. Pearson HA, Lobel JS, Kocoshis SA. A new syndrome of refractory sideroblastic anemia with vacuolization of marrow precursors and exocrine dysfunction. J Pediatr 1979;95:976-984.

6. Artuch R, Pavia C, Playan A, Vilaseca MA, Colomer J, Valls C, Rissech M, Gonzalez MA, Pou A, Briones P, Montoya J, Pineda M. Multiple endocrine involvement in two pediatric patients with Kearns-Sayre syndrome. Horm Res 1998;50:99-104.

7. Becher MW, Wills ML, Noll WW, Hurko O, Price DL. Kearns-Sayre syndrome with features of Pearson's marrow-pancreas syndrome and a novel 2905-base pair mitochondrial DNA deletion. Hum Pathol 1999;30:577-581.

8. Boles RG, Roe T, Senaheera D, Wong LJC. Mitochondrial DNA deletion with Kearns Sayre syndrome in a child with Addison disease. Eur J Pediatr 1998;157:643647.

9. Bruno C, Minetti C, Tang Y, Magalhaes PJ, Santorelli FM, Shanske S, Bado M, Cordone G, Gatti R, DiMauro S. Primary adrenal insufficiency in a child with a mitochondrial DNA deletion. J Inherit Metab Dis 1998;21:155-161.

10. Lacbawan FL, Tifft CJ, Amaya M, Pennybacker M, Weistein S, Wong LJC. Clinical heterogeneity in mitochondrial DNA deletion disorders: a diagnostic challenge. Am J Med Genet 2000;95:272-274.

11. Van den Ouweland JMW, de Klerk JBC, van de Corput MP, Dirks RW, Raap AK, Scholte HR, Huijmans JGM, 't Hart LM, Bruining GJ, Maassen JA. Characterization of a novel mitochondrial DNA deletion in a patient with a variant of the Pearson marrow-pancreas syndrome. Eur J Hum Genet 2000;8:195-203.

12. Boles RG, Chun N, Senadheera D, Wong LJ. Cyclic vomiting syndrome and mitochondrial DNA mutations. Lancet 1997;350:1299-1300.

13. Gurakan B, Ozbek N, Baran B, Demirhan B. Fatal acidosis in a neonate with Pearson syndrome. Turk J Pediatr 1999;41:361-364.

14. Muraki K, Nishimura S, Goto Y, Nonaka I, Sakura N, Ueda K. The association between haematological manifestation and mtDNA deletions in Pearson syndrome. J Inherit Metab Dis 1997;20:697-703.

15. Barshop BA, Nyhan WL, Naviaux RK, McGowan KA, Friedlander M, Haas RH. Kearns-Sayre syndrome presenting as 2-oxoadipic aciduria. Mol Genet Metab 2000; 69:64-68.

16. Isotani H, Fukumoto Y, Kawamura H, Furukawa K, Ohsawa N, Goto Y, Nishino I, Nonaka I. Hypoparathyroidism and insulin-dependent diabetes mellitus in a patient with Kearns-Sayre syndrome harbouring a mitochondrial DNA deletion. Clin Endocrinol 1996;45:637-641.

17. Wilichowski E, Gruters A, Kruse K, Rating D, Beetz R, Korenke GC, Ernst BP, Christen H, Hanefeld F. Hypoparathyroidism and deafness associated with pleioplasmic large scale rearrangements of the mitochondrial DNA: a clinical and molecular genetic study of four children with Kearns-Sayre syndrome. Pediatr Res 1997; 41:193-200.

18. Moraes CT, DiMauro S, Zaviana M, Lombes A, Shanske S, Miranda AF, Nakase H, Bonilla E, Werneck LC, Servidei S, Nonaka I, Koga Y, Spiro AJ, Brownell KW, Schmidt B, Schotland DL, Zupanc M, DeVivo DC, Schon EA, Rowland LP. Mitochondrial DNA deletions in progressive external ophthalmoplegia and Kearns-Sayre syndrome. N Engl J Med 1989;320:1293-1299.

19. Schroder R, Vielhaber S, Wiedemann FR, Kornblum C, Papassotiropoulos A, Broich P, Zierz S, Elger CE, Reichmann H, Seibel P, Klockgether T, Kunz W. New insights into the metabolic consequences of large-scale mtDNA deletions: a quantitative analysis of biochemical, morphological, and genetic findings in human skeletal muscle. J Neuropathol Exp Neurol 2000;59:353-360.

20. Liang M, Wong LJC. Yield of mtDNA mutation analysis in 2000 patients. Am J Med Genet 1998;77:395-400. 


\section{Wong}

21. Wong LJC, Senadheera D. Direct detection of multiple point mutations in mitochondrial DNA. Clin Chem 1997;43:1857-1861.

22. Moslemi A, Selimovic N, Bergh C-H, Oldfors A. Fatal dilated cardiomyopathy associated with a mitochondrial DNA deletion. Cardiology 2000;94:68-71.

23. Marin-Garcia J, Goldenthal MJ, Sarnat HB. Kearns-Sayre syndrome with a novel mitochondrial DNA deletion. J Child Neurol 2000;15:555-558.

24. Campos Y, Martin MA, Caballero C, Rubio JC, de la Cruz F, Tunon T, Arenas J. Single large-scale mitochondrial DNA deletion in a patient with encephalopathy, cardiomyopathy, and prominent intestinal pseudo-obstruction. Neuromuscul Disord 2000;10:56-58.

25. Simaan EM, Mikati MA, Touma EH, Rotig A. Unusual presentation of Kearns-Sayre syndrome in early childhood. Pediatr Neurol 1999;21:830-831.

26. Seyrantepe V, Kale G, Topaloglu H, Alikasifoglu A, Ozguc M. Common deletion of mitochondrial DNA in a 5-year-old girl with failure to thrive, ptosis, ophthalmoplegia and ragged-red fibers. Brain Dev 1999;21:413-415.

27. Zanssen S, Molnar M, Buse G, Schroder JM. Mitochondrial cytochrome b gene deletion in Kearns-Sayre syndrome associated with a subclinical type of peripheral neuropathy. Clin Neuropathol 1998;17:291-296.

28. Graff C, Wredenberg A, Silva JP, Bui T-H, Borg K, Larsson N-G. Complex genetic counselling and prenatal analysis in a woman with external ophthalmoplegia and deleted mtDNA. Prenat Diagn 2000;20:426-431.

29. Ishikawa Y, Goto Y-I, Ishikawa Y, Minami R. Progression in a case of Kearns-Sayre syndrome. J Child Neurol 2000;15:750-755.

30. Moraes CT, Ciacci F, Bonilla E, Ionasescu V, Schon EA, DiMauro S. A mitochondrial tRNA anticodon swap associated with a muscle disease. Nat Genet 1993;4:284288.

31. Weber K, Wilson JN, Taylor L, Brierley E, Johnson MA, Turnbull DM, Bindoff LA. A new mtDNA mutation showing accumulation with time and restriction to skeletal muscle. Am J Hum Genet 1997;60:373-380.

32. Sue CM, Quigley A, Katsabanis S, Kapsa R, Crimmins DS, Byrne E, Morris JGL. Detection of MELAS A3243G point mutation in muscle, blood and hair follicles. Neurol Sci 1998;161:36-39.

33. Siregar NC, Jean-Francois MJB, Blok RB, Byrne E. Genotypic and phenotypic changes in exhaustively grown cell lines from mitochondrial cytopathy patients. Muscle Nerve 1998;21:599-609. 